\title{
IMPACT OF ORGANIC AND INORGANIC NITROGEN FERTILIZERS ON WASHINGTON NAVEL ORANGE TREES. II. FRUIT QUALITY DURING COLD STORAGE
}

\author{
H. A. Ennab(1), M. A. El Shemy ${ }^{(2)}$ and M. H. Abd El Aziz(2) \\ Citrus Research Department ${ }^{(1)}$ and Handling Research Department ${ }^{(2)}$ \\ Horticulture Research Institute, Agriculture Research Center, Giza, Egypt \\ Received: Jul. 22, 2019 \\ Accepted: Aug. 25, 2019
}

\begin{abstract}
The present study was carried out during 2017-2018 and 2018-2019 seasons on 20 year old Washington navel orange trees grown in a private orchard in Kafr El Sheikh governorate, Egypt, to evaluating the effects of poultry manure and/or ammonium sulphate on fruit quality and storability of Washington navel orange fruits during cold storage. At harvest time, fruit samples were transported to laboratory of Sakha Horticulture Research Station, Kafr El-Sheikh Governorate, Egypt. Fruit samples were stored at cold storage $\left(3 \pm 1{ }^{\circ} \mathrm{C}\right.$ and $\left.90-95 \% \mathrm{RH}\right)$ for 60 days. Fruit quality was determined at 15 days intervals from storage to determine the changes of fruit characters. The obtained results revealed that, Washington navel orange trees receiving $305.8 \mathrm{~kg} / \mathrm{feddan}$ ammonium sulphate +2.73 ton/feddan poultry manure $\left(T_{3}\right)$ was the most effective treatment in maintaining the quality of Washington navel oranges during cold storage $\left(3 \pm 1{ }^{\circ} \mathrm{C}\right.$ and $\left.90-95 \% R H\right)$ which was significantly indicated by the lowest percentages of weight loss and decay. Also, this treatment $\left(T_{3}\right)$ gave the highest fruit firmness, higher SSC and SSC/acid ratio, while it gave moderate level of titratable acidity and ascorbic acid compared to the other treatments. Therefore, it could be recommended that, fertilizing Washington navel orange trees with $305.8 \mathrm{~kg} / \mathrm{feddan}$ ammonium sulphate +2.73 ton/feddan poultry manure $\left(T_{3}\right)$ considers as effective treatments in producing fruit with high quality at harvest time and help to maintaining the quality tell 60 days of cold storage.
\end{abstract}

Key words: Citrus sinensis, poultry manure, storability, juice quality, orange

\section{INTRODUCTION}

Fertilization is the most important inputs which directly affect the tree growth, yield and fruit quality. Nitrogen is easily absorbed and distributed in plant cell and plays an important role in essentially all life processes of plant. Citrus tree needs to nitrogen in large amounts but fairly expensive to supply. Furthermore, nitrogen is easily loss in the field causes a serious environmental problem which giving rise to soil and water pollution (Masclaux-Daubresse et al., 2010). On the other words, mineral nitrogen fertilizers cause the accumulation of harmful residual substances like $\mathrm{NO}_{3}$ and $\mathrm{NO}_{2}$ in fruits, which reflected on human health (Caruso et al., 2011 and Ennab et al., 2018). So, organic sources and natural raw materials have received much attention from growers and researchers. Recent approaches have included the use of organic material such as organic manures, compost, biofertilizers and plants extracts to improving productivity and access to safe fruits for local consumer and high exportation potential as well as reduce the costs. Several studies were done for producing citrus fruits through avoid application of all or part of nitrogen chemical fertilizers and encouraging the application of organic nitrogen and biofertilizers (Abd El Migeed 
H. A. Ennab, et al.,

et al., 2007; Mansour and Shaaban 2007; Ahmed et al., 2013 and Ibrahim and Maklad 2014). Soil fertilization has influence on the chemical content of citrus fruit and its storability. It has been known that high level of nitrogen can result in increasing disorder incidence of Washington navel orange during storage (Kassem and EI Sabrout, 2002). Potassium may have an influence on the incidence of physiological disorders; it has an important role in the maintenance of cellular organization by regulation by the permeability of cell membranes (Marschner, 1995). Nutrition of Copper may have an even stronger role for reducing fungal diseases and improved fruit quality (Malhi et al., 1989). A few studies were done to comparing the effect between organic and inorganic fertilizers applications on fruit quality during cold storage (Zaghloul et al., 2010; Omer and Belal 2013; Candir et al., 2013;
Ceglie et al., 2016 and Mehmood et al., 2016).

So, the present study was conducted to evaluate the effect of preharvest application of poultry manure as a source of organic nitrogen and mineral nitrogen on physical and chemical properties of Washington navel orange fruits during cold storage.

\section{MATERIALS AND METHODS}

A field experiment was carried out in a private orchard at Kafr EI Sheikh Governorate Egypt during 2018 and 2019 seasons, on twenty years old Washington navel orange (Citrus sinensis Osbeck) trees budded on sour orange (Citrus aurantium L.) rootstock, planted at $5 \times 5$ meter apart in clay soil under flood irrigation system. Soil and poultry manure used in this study were analyzed according to Page et al., (1982); the data was illustrated in Table 1.

Table 1: Analysis of poultry manure, and some physical and chemical characters of the experimental soil

\begin{tabular}{|c|c|c|c|c|}
\hline \multicolumn{3}{|c|}{ Soil analysis } & \multicolumn{2}{|c|}{ Poultry manure analysis } \\
\hline \multirow{2}{*}{ Parameters } & \multicolumn{2}{|c|}{ Soil depth cm } & \multirow{2}{*}{ Parameters } & \multirow{2}{*}{ Values } \\
\hline & $0-30$ & $30-60$ & & \\
\hline Sand \% & 6.84 & 6.84 & Weight of $\mathbf{m}^{3} \mathbf{k g}$ & 495.32 \\
\hline Silt \% & 33.87 & 30.74 & Moisture \% & 18.45 \\
\hline Clay \% & 59.29 & 62.42 & Organic matter \% & 35.42 \\
\hline Texture & Clay & Clay & Organic carbon \% & 26.33 \\
\hline pH 1:2.5 & 8.18 & 8.20 & pH 1:10 & 6.73 \\
\hline$E C \mathrm{dSm}^{-1} 1: 5$ & 1.20 & 098 & $E C \mathrm{dSm}^{-1} 1: 5$ & 0.89 \\
\hline Organic matter \% & 1.30 & 0.98 & $\mathrm{C} / \mathrm{N}$ ratio & 11.44 \\
\hline $\mathrm{K}^{+} \mathrm{meq} / \mathrm{l}$ & 0.50 & 0.43 & $\mathbf{N} \%$ & 2.30 \\
\hline $\mathrm{Ca}^{++} \mathrm{meq} / \mathrm{l}$ & 4.70 & 4.53 & $\mathbf{P} \%$ & 0.91 \\
\hline $\mathrm{Mg}^{++} \mathrm{meq} / \mathrm{l}$ & 3.77 & 3.35 & $\mathrm{~K} \%$ & 1.36 \\
\hline $\mathrm{Na}^{+}$meq/l & 12.87 & 11.48 & $\mathrm{Ca} \%$ & 0.180 \\
\hline $\mathrm{HCO}_{3} \cdot{ }^{-} \mathrm{meq} / \mathrm{l}$ & 4.40 & 4.31 & Mg \% & 0.180 \\
\hline $\mathrm{Cl}^{-}$meq/l & 6.69 & 6.23 & Fe ppm & 241.75 \\
\hline $\mathrm{SO}_{4}^{--} \mathrm{meq} / \mathrm{l}$ & 10.75 & 9.25 & Mn ppm & 127.17 \\
\hline $\mathrm{CO}_{3}^{--}$ & 0.00 & 0.00 & Zn ppm & 152.76 \\
\hline Total N , \% & 0.155 & 0.112 & -- & - \\
\hline Available $P, \mathrm{mg} / \mathrm{kg}$ soil & 15.25 & 7.90 & -- & -- \\
\hline Available $\mathrm{K}, \mathrm{mg} / \mathrm{kg}$ soil & 1155 & 800 & -- & -- \\
\hline
\end{tabular}


Forty five trees uniform in growth, vigor and productivity were selected, and subjected to study the effect of poultry manure and ammonium sulphate as a source of nitrogen fertilization on fruit quality of Washington navel orange during cold storage. The trees were exposed to the same cultural practices commonly adopted on the orchard, except those dealing with application of organic and inorganic nitrogen fertilizers. Trees were arranged in a randomized complete block design, each treatment replicated three times with three trees per replicate.

The experiment included five treatments as follows:

$\mathrm{T}_{1}$ : $100 \%$ recommended dose of mineral $N$ (126 unites $N /$ feddan) completely via ammonium sulphate $20.6 \% \mathrm{~N}$ at rate of $611.6 \mathrm{~kg} / \mathrm{feddan}, \quad$ (3.64 kg/tree/year),

$\mathrm{T}_{2}: \mathbf{6 6 . 6} \%$ recommended dose of mineral N (126 unites N/feddan) via ammonium sulphate at rate of $\mathbf{4 0 7 . 7}$ kg/feddan, (2.42 kg/tree/year) + 33.3\% via poultry manure $2.30 \% \mathrm{~N}$ at rate of 1.82 ton/feddan, (10.8 kg/tree/year),

$\mathrm{T}_{3}: 50 \%$ recommended dose of mineral $\mathrm{N}$ (126 unites $\mathrm{N} / \mathrm{feddan}$ ) via ammonium sulphate at rate of $305.8 \mathrm{~kg} / \mathrm{feddan}$, $(1.82 \mathrm{~kg} /$ tree/year) $+50 \%$ via poultry manure $2.30 \% \mathrm{~N}$ at rate of $\mathbf{2 . 7 3}$ ton/feddan, (16.2 kg/tree/year),

$\mathrm{T}_{4}: 33.3 \%$ recommended dose of mineral N (126 unites N/feddan) via ammonium sulphate at rate of $\mathbf{2 0 3 . 8}$ kg/feddan, (1.21 kg/tree/year) + 66.6\% via poultry manure $2.30 \% \mathrm{~N}$ at rate of 3.64 ton/feddan, (21.6 kg/tree/year), and

$\mathrm{T}_{5}$ : $100 \%$ recommended dose of mineral N (126 unites $\mathrm{N} /$ feddan) completely via poultry manure $2.30 \% \mathrm{~N}$ at rate of 5.46 ton/feddan, (32.5 kg/tree/year).

The source of inorganic $\mathbf{N}$ fertilizers was ammonium sulphate $20.6 \% \mathrm{~N}$ ). It was splitted into three equal doses and added at the first week of March, June and August. The amounts of poultry manure were broadcasted and incorporated into the root zone of trees in winter service at December in both seasons. At harvest time, fruits of each replicate were picked separately by clipper to reduce any mechanical injuries and packed in plastic boxes. Fruit samples were directly transported to laboratory of Sakha Horticulture Research Station, Kafr El-Sheikh Governorate, Egypt. Fruits were washed with following tap water to remove the adherent particles of the dirt and foreign materials and then dipped in $1 \%$ Clorox solution. The fruits ear dried, a quick sorting and packed in plastic boxes (dimensions $30 * 50 * 12 \mathrm{~cm}$ ), each box contain $(5 \mathrm{Kg})$. Each treatment represented by four plastic boxes. Ten citrus fruits per plastic box weighted and labeled for determining fruit weight loss every 15 days of cold storage. All boxes were stored at $3 \pm 1{ }^{\circ} \mathrm{C}$ with $90-95 \% \mathrm{RH}$. One plastic box per treatment was taken out of storage to evaluate fruit quality parameters every 15 days of cold storage till 60 days as follows:

\section{Weight loss $\%$ :}

Fruits were weighed at zero time (beginning) and 15 days intervals during the storage period. Fruit weight was recorded, and then the percentages of weight loss were calculated according to the following equation:

Fruit weight loss $\%=\left(W_{I}-W_{s}\right) / W_{I} \times 100$ Where, $W_{I}=$ fruit weight at initial period. Ws = fruit weight at sampling period.

\section{Fruit decay\%:}

Fruit decay\% was determined by calculating the number of decayed fruits on the sampling date and expressed as a percentage of decayed fruits according to the following equation:

Fruit decay $\%=\{$ NO. of decayed fruits $\div$ Initial NO. of stored fruits $\} \times 100$ 


\section{Fruit firmness $\mathrm{kg} / \mathrm{cm}^{2}$}

Fruit firmness was examined in two sides of the fruit using pressure tester (Digital force-Gouge Model FGV-0.5A to FGV-100A.shimpo instruments) and expressed as $\mathbf{k g} / \mathrm{cm}^{2}$.

\section{Soluble solid content $\%$ :}

Soluble solid content of the fruits were measured by hand refractometer.

\section{Titratable acidity\%:}

The acidity of the fruit juice was estimated by titrating against standard alkali solution $(0.1 \mathrm{~N} \mathrm{NaOH})$ using the phenolphthalein indicator and expressed as percentage of citric acid/100 ml of juice according to (A.O.A.C 1990).

\section{SSC/acid ratio:}

SSC/acid ratio was estimated.

7. Ascorbic acid $\mathrm{mg} / 100 \mathrm{ml}$ juice:

Ascorbic acid content of fruits was measured by 2, 6-dichlorophenol indophenol titration solution to a pink end-point, and expressed as $\mathrm{mg}$ ascorbic acid/100 ml juice according to method described by Rangana, (1977).

Statistical analysis:

Statistical analysis was done as analysis of variance according to Snedecor and Cochran (1990) and the differences among treatment means were compared with Duncan multiple range tests at $5 \%$ level according Duncan (1955).

\section{RESULTS AND DISCUSSION}

\section{Weight loss \%}

Data in Table 2 show the changes in fruit weight loss percentage of Washington navel orange trees fertilized by organic and inorganic nitrogen fertilizers as preharvest treatments, stored at $3 \pm 1^{\circ} \mathrm{C}$ with $90-95 \% \mathrm{RH}$ for 60 days. The results revealed that fruit weight loss $\%$ increased as the storage period progressed in both seasons. Also, weight loss percentage was significantly decreased with increasing poultry manure percentages for replacing mineral nitrogen. In this respect, the highest percentage of weight loss was observed in $\mathrm{T}_{1}$ ( $100 \%$ inorganic nitrogen). Whereas, $\mathrm{T}_{3}(\mathbf{5 0} \%$ inorganic nitrogen + $50 \%$ organic nitrogen) and $\mathrm{T}_{4}(33.3 \%$ inorganic nitrogen $+66.6 \%$ organic nitrogen) were superior in reducing fruit weight loss percentage as compared to other treatments. Generally, the results indicated that combined application of poultry manure plus mineral nitrogen dose was effective in reducing fruit weight loss percentage of Washington navel orange fruits during storage at $3 \pm 1^{\circ} \mathrm{C}$ with $85-95 \% \mathrm{RH}$ for 60 days especially application of $305.8 \mathrm{~kg} / \mathrm{feddan}$ ammonium sulphate +2.73 ton/feddan poultry manure $\left(T_{3}\right)$. Similar results were obtained by Omar and Belal (2013) on Washington navel orange and Mehmood et al., (2016) on Kinnow mandarin. In this respect, Sharma et al., (2016) who recorded highest weight loss of guava fruits was obtained with the treatment of $100 \% \mathrm{~N}$ from urea, while weight loss $\%$ was minimum with the treatment of $75 \%$ $\mathrm{N}$ supplemented through poultry manure and rest of $\mathbf{N}$ through urea during storage under ambient conditions.

The loss of water from fresh fruit after harvest is a serious problem, causing shrinkage and weight loss. The enhance in fruit weight loss as a result of organic and inorganic fertilization maybe due to the integration of organic and inorganic fertilizers, which might have accelerated the better uptake and accumulation of $\mathrm{Ca}$ and $P$. It has been observed that when organic status of the soil was increased, it would also have helped to certain extent the maintenance of cell wall turgidity as the $\mathrm{Ca}$ is one of the important constituents of cell wall. This reduce dehydration in fruits, reduce water loss, retain the shriveling of the fruit skin, delay the fruit ripening, and thereby delay the decline in fruit quality. 
Table 2: Effect of organic and inorganic nitrogen fertilizers on weight loss \% of Washington navel orange fruits during cold storage at $3 \pm 1^{\circ} \mathrm{C}$ and $90-95 \% \mathrm{RH}$

\begin{tabular}{|c|c|c|c|c|c|c|}
\hline Treatments & 0 day & $\begin{array}{l}15 \\
\text { day }\end{array}$ & $\begin{array}{l}30 \\
\text { day }\end{array}$ & $\begin{array}{l}45 \\
\text { day }\end{array}$ & $\begin{array}{l}60 \\
\text { day }\end{array}$ & Mean \\
\hline & \multicolumn{6}{|c|}{ 2017-2018 season } \\
\hline$T_{1}: 100 \%$ inorganic & 0.00 & $1.26 \mathrm{~b}$ & $4.10 \mathrm{a}$ & $6.21 \mathrm{a}$ & $12.33 \mathrm{a}$ & $4.78 \mathrm{a}$ \\
\hline $\mathrm{T}_{2}: 66.6 \%$ inorganic $+33.6 \%$ organic & 0.00 & $1.34 \mathrm{a}$ & $2.30 \mathrm{~b}$ & $3.39 \mathrm{~b}$ & $7.19 \mathrm{~b}$ & $2.84 \mathrm{~b}$ \\
\hline $\mathrm{T}_{3}: \mathbf{5 0 \%}$ inorganic $+\mathbf{5 0} \%$ organic & 0.00 & $1.25 \mathrm{~b}$ & $1.92 \mathrm{c}$ & $2.79 \mathrm{e}$ & $5.11 \mathrm{c}$ & $2.21 \mathrm{~d}$ \\
\hline $\mathrm{T}_{4}: 33.3 \%$ inorganic $+66.6 \%$ organic & 0.00 & $1.27 \mathrm{~b}$ & $2.26 \mathrm{~b}$ & $3.00 \mathrm{~d}$ & $5.50 \mathrm{c}$ & $2.40 \mathrm{~cd}$ \\
\hline $\mathrm{T}_{5}: 100 \%$ organic & 0.00 & $1.32 \mathrm{a}$ & $2.28 \mathrm{~b}$ & $3.29 \mathrm{c}$ & $5.87 \mathrm{bc}$ & $2.55 \mathrm{c}$ \\
\hline \multirow[t]{2}{*}{ Mean } & $0.00 \mathrm{e}$ & $1.28 \mathrm{~d}$ & $2.57 \mathrm{c}$ & $3.73 \mathrm{~b}$ & $7.20 \mathrm{a}$ & --- \\
\hline & \multicolumn{6}{|c|}{ 2018-2019 season } \\
\hline $\mathrm{T}_{1}: 100 \%$ inorganic & 0.00 & $2.89 \mathrm{a}$ & $3.94 \mathrm{a}$ & $5.94 \mathrm{a}$ & $11.75 \mathrm{a}$ & $4.90 \mathrm{a}$ \\
\hline $\mathrm{T}_{2}: 66.6 \%$ inorganic $+33.6 \%$ organic & 0.00 & $1.67 \mathrm{~b}$ & $2.10 \mathrm{~b}$ & $5.81 \mathrm{~b}$ & $7.80 \mathrm{~b}$ & $3.47 \mathrm{~b}$ \\
\hline $\mathrm{T}_{3}: \mathbf{5 0} \%$ inorganic $+\mathbf{5 0} \%$ organic & 0.00 & $1.47 \mathrm{~d}$ & $1.74 \mathrm{~d}$ & $3.65 \mathrm{e}$ & $5.88 \mathrm{e}$ & $2.54 \mathrm{e}$ \\
\hline $\mathrm{T}_{4}: 33.3 \%$ inorganic $+66.6 \%$ organic & 0.00 & $1.54 \mathrm{c}$ & $1.77 \mathrm{~d}$ & $4.20 \mathrm{~d}$ & $6.35 \mathrm{~d}$ & $2.77 \mathrm{~d}$ \\
\hline $\mathrm{T}_{5}: 100 \%$ organic & 0.00 & $1.55 \mathrm{c}$ & $1.98 \mathrm{c}$ & $4.84 \mathrm{c}$ & $7.17 \mathrm{c}$ & $3.10 \mathrm{c}$ \\
\hline Mean & $0.00 \mathrm{e}$ & $1.82 \mathrm{~d}$ & $2.30 \mathrm{c}$ & $4.88 \mathrm{~b}$ & $7.79 \mathrm{a}$ & --- \\
\hline
\end{tabular}

\section{Decay $\%$}

Data presented in Table 3 show the effect of organic and inorganic nitrogen fertilizers on decay \% of Washington navel orange fruits stored at $3 \pm 1^{\circ} \mathrm{C}$. The results showed that, there was no fruit decay appeared up to15 days of cold storage, but it increased with increase of storage period tell 60 days. All treatments included poultry manure as organic source significantly reduced fruit decay compared to $100 \%$ mineral nitrogen only. In this trend, application of $\mathbf{3 0 5 . 8}$ $\mathrm{kg} /$ feddan ammonium sulphate +2.73 ton/feddan poultry manure $\left(T_{3}\right)$ showed to be the superior one in reducing fruit decay percentage during all storage periods tell 60 days of storage as compared with treatments in both seasons. On the other hand, $T_{1}(100 \%$ inorganic nitrogen) treatment had the highest decay percentage with significant differences between $T_{1}$ and other treatments in both seasons. Similar results were obtained by Benge et al., (2000) on kiwifruit. Also, Omar and Belal
(2013) revealed that, compost tea and filtered biogas slurry liquid foliar applications at 50 and $100 \%$ were effective to reducing fruit decay $\%$ of Washington navel orange compared to control treatment.

\section{Fruit firmness $\mathrm{Kg} / \mathrm{cm}^{2}$}

Data in Table 4 indicated that, combined applications of poultry manure with mineral nitrogen at different percentages significantly improved fruit firmness of Washington navel orange fruits during cold storage as compared to application of mineral nitrogen only in both seasons. Fruit firmness was decreased during storage period, and this was noticed with the all measurement times. At the end of storage period, the higher fruit firmness was recorded with applications of $T_{4}, T_{5}$ and $T_{3}$ however; significantly the lowest values were noticed in $T_{1}$ in both seasons. This finding is harmony with that of Ceglie et al., (2016) and Taha et al., (2018). 
H. A. Ennab, et al.,

Table 3: Effect of organic and inorganic nitrogen fertilizers on decay \% of Washington navel orange fruits during cold storage at $3 \pm 1^{\circ} \mathrm{C}$ and $90-95 \% \mathrm{RH}$.

\begin{tabular}{|c|c|c|c|c|c|c|}
\hline Treatments & 0 day & $\begin{array}{c}15 \\
\text { days }\end{array}$ & $\begin{array}{c}30 \\
\text { days }\end{array}$ & $\begin{array}{c}45 \\
\text { days }\end{array}$ & $\begin{array}{c}60 \\
\text { days }\end{array}$ & Mean \\
\hline & \multicolumn{6}{|c|}{ 2017-2018 season } \\
\hline $\mathrm{T}_{1}: 100 \%$ inorganic & 0.00 & 0.00 & $10.49 \mathrm{a}$ & $12.92 \mathrm{a}$ & 16.78 a & $8.03 \mathrm{a}$ \\
\hline $\mathrm{T}_{2}: 66.6 \%$ inorganic $+33.6 \%$ organic & 0.00 & 0.00 & $8.70 \mathrm{~b}$ & $12.38 \mathrm{a}$ & $14.45 \mathrm{~b}$ & $7.10 \mathrm{~b}$ \\
\hline $\mathrm{T}_{3}: \mathbf{5 0 \%}$ inorganic $+\mathbf{5 0} \%$ organic & 0.00 & 0.00 & $1.87 \mathrm{~d}$ & $6.15 \mathrm{c}$ & $11.73 \mathrm{c}$ & $3.95 \mathrm{~d}$ \\
\hline $\mathrm{T}_{4}: 33.3 \%$ inorganic $+66.6 \%$ organic & 0.00 & 0.00 & $2.90 \mathrm{c}$ & $8.46 \mathrm{~b}$ & $12.88 \mathrm{bc}$ & $4.84 \mathrm{c}$ \\
\hline$T_{5}: 100 \%$ organic & 0.00 & 0.00 & $2.91 \mathrm{c}$ & $8.47 \mathrm{~b}$ & $12.5 \mathrm{bc}$ & $4.78 \mathrm{c}$ \\
\hline \multirow[t]{2}{*}{ Mean } & $0.00 \mathrm{~d}$ & $0.00 \mathrm{~d}$ & $5.37 \mathrm{c}$ & $9.67 \mathrm{~b}$ & $13.68 \mathrm{a}$ & --- \\
\hline & \multicolumn{6}{|c|}{ 2018-2019 season } \\
\hline $\mathrm{T}_{1}: 100 \%$ inorganic & 0.00 & 0.00 & $10.58 \mathrm{a}$ & $13.44 \mathrm{a}$ & $15.93 \mathrm{a}$ & $7.99 \mathrm{a}$ \\
\hline $\mathrm{T}_{2}: 66.6 \%$ inorganic $+33.6 \%$ organic & 0.00 & 0.00 & $6.31 \mathrm{~b}$ & $11.63 \mathrm{a}$ & $12.15 \mathrm{~b}$ & $6.01 \mathrm{~b}$ \\
\hline $\mathrm{T}_{3}: 50 \%$ inorganic $+50 \%$ organic & 0.00 & 0.00 & $2.98 \mathrm{~d}$ & $5.89 \mathrm{~b}$ & $11.88 \mathrm{~b}$ & $4.15 \mathrm{c}$ \\
\hline $\mathrm{T}_{4}: 33.3 \%$ inorganic $+66.6 \%$ organic & 0.00 & 0.00 & $3.14 \mathrm{~d}$ & $8.22 \mathrm{~b}$ & $12.10 \mathrm{~b}$ & $4.69 \mathrm{c}$ \\
\hline$T_{5}: 100 \%$ organic & 0.00 & 0.00 & $5.13 \mathrm{c}$ & $8.48 \mathrm{~b}$ & $12.26 \mathrm{~b}$ & $5.17 \mathrm{bc}$ \\
\hline Mean & $0.00 \mathrm{~d}$ & $0.00 \mathrm{~d}$ & $5.62 \mathrm{c}$ & $9.53 \mathrm{~b}$ & $12.86 \mathrm{a}$ & --- \\
\hline
\end{tabular}

Table 4: Effect of organic and inorganic nitrogen fertilizers on fruit firmness $\left(\mathrm{kg} / \mathrm{cm}^{2}\right)$ of Washington navel orange fruits during cold storage at $3 \pm 1^{\circ} \mathrm{C}$ and $90-95 \% \mathrm{RH}$

\begin{tabular}{|c|c|c|c|c|c|c|}
\hline Treatments & 0 day & 15 days & 30 days & 45 days & 60 days & Mean \\
\hline & \multicolumn{6}{|c|}{ 2017-2018 season } \\
\hline$T_{1}: 100 \%$ inorganic & $55.17 \mathrm{e}$ & $52.52 \mathrm{e}$ & $49.36 \mathrm{e}$ & $42.45 \mathrm{e}$ & $32.28 \mathrm{e}$ & $46.35 \mathrm{e}$ \\
\hline $\mathrm{T}_{2}: 66.6 \%$ inorganic $+33.6 \%$ organic & $72.83 \mathrm{~d}$ & $69.65 \mathrm{~d}$ & $64.96 \mathrm{~d}$ & $57.61 \mathrm{~d}$ & $53.09 \mathrm{~d}$ & $63.62 \mathrm{~d}$ \\
\hline $\mathrm{T}_{3}: \mathbf{5 0} \%$ inorganic $+\mathbf{5 0} \%$ organic & $84.75 \mathrm{~b}$ & $79.33 \mathrm{~b}$ & $78.45 \mathrm{~b}$ & $71.59 \mathrm{~b}$ & $61.24 \mathrm{~b}$ & $75.07 \mathrm{~b}$ \\
\hline $\mathrm{T}_{4}: 33.3 \%$ inorganic $+66.6 \%$ organic & 91.46 a & 85.87 a & 83.16 a & 75.69 a & $66.90 \mathrm{a}$ & 80.61 a \\
\hline$T_{5}: 100 \%$ organic & $78.80 \mathrm{a}$ & $74.05 \mathrm{c}$ & $71.91 \mathrm{c}$ & $64.60 \mathrm{c}$ & $57.18 \mathrm{c}$ & $69.30 \mathrm{c}$ \\
\hline \multirow[t]{2}{*}{ Mean } & $76.60 \mathrm{a}$ & $72.28 \mathrm{~b}$ & $69.56 \mathrm{c}$ & $62.38 \mathrm{~d}$ & $54.13 \mathrm{e}$ & -- \\
\hline & \multicolumn{6}{|c|}{ 2018-2019 season } \\
\hline$T_{1}: 100 \%$ inorganic & $59.34 \mathrm{e}$ & 60.49 e & 56.44 e & $46.85 \mathrm{e}$ & $37.77 \mathrm{e}$ & $52.17 \mathrm{e}$ \\
\hline $\mathrm{T}_{2}: 66.6 \%$ inorganic $+33.6 \%$ organic & $77.26 \mathrm{c}$ & $70.44 \mathrm{~d}$ & $66.78 \mathrm{~d}$ & $56.19 \mathrm{~d}$ & $53.91 \mathrm{~d}$ & $64.91 \mathrm{~d}$ \\
\hline $\mathrm{T}_{3}: \mathbf{5 0} \%$ inorganic $+\mathbf{5 0} \%$ organic & $85.40 \mathrm{a}$ & $80.37 \mathrm{~b}$ & 77.22 b & $66.97 \mathrm{c}$ & $56.83 \mathrm{c}$ & $73.35 \mathrm{~b}$ \\
\hline $\mathrm{T}_{4}: 33.3 \%$ inorganic $+66.6 \%$ organic & $80.20 \mathrm{~b}$ & $77.63 \mathrm{c}$ & $73.90 \mathrm{c}$ & $68.26 \mathrm{~b}$ & $59.64 \mathrm{~b}$ & $71.92 \mathrm{c}$ \\
\hline$T_{5}: 100 \%$ organic & $85.52 \mathrm{a}$ & 82.36 a & $78.81 \mathrm{a}$ & $71.85 \mathrm{a}$ & $63.69 \mathrm{a}$ & $76.44 \mathrm{a}$ \\
\hline Mean & 77.54 a & $74.25 \mathrm{~b}$ & $70.63 \mathrm{c}$ & $62.02 \mathrm{~d}$ & $54.36 \mathrm{e}$ & --- \\
\hline
\end{tabular}




\section{Soluble solids content (SSC):}

Data in Table 5 show the results of soluble solid content (SSC \%) of organic and inorganic nitrogen fertilizers application on Washington navel orange fruits during cold storage periods at $3 \pm 1^{\circ} \mathrm{C}$. The results indicated that soluble solid content (SSC \%) of Washington navel orange fruits slightly increased as storage time progressed. At the end of the storage period, application of $\mathrm{T}_{3}(50 \%$ inorganic nitrogen $+\mathbf{5 0 \%}$ organic nitrogen) recorded the highest SSC \% in fruits followed by $T_{1} \quad(100 \%$ inorganic nitrogen) in the first season and $T_{5}(100 \%$ organic nitrogen) in the second one. Meanwhile, the lowest value was found in $\mathrm{T}_{4} \quad(33.3 \%$ inorganic nitrogen $+66.6 \%$ organic nitrogen) treatment in the first season and in $T_{1} \quad(100 \%$ inorganic nitrogen) in the second season. These results are in agreement with the findings of Omar and Belal (2013) and El Sayed and EI Sherif (2017) on Washington navel orange fruits. Thus, using combined applications of poultry manure with doses of mineral nitrogen especially application of $\mathrm{T}_{3}(50 \%$ inorganic nitrogen $+50 \%$ organic nitrogen) maintain high level of soluble solids content percent at different period of cold storage compared to other treatments. The increasing soluble solids content with organic manure application maybe related to the hydrolytic activities in starch, the increased activity of enzymes responsible for the hydrolysis of starch to soluble sugars, and the conversion of starch to sugar, which indicates that the fruits are at the ripening process. This explanation agrees with those results obtained by Candir et al., (2013) on Washington navel orange.

Table 5: Effect of organic and inorganic nitrogen fertilizers on SSC \% of Washington navel orange fruits during cold storage at $3 \pm 1^{\circ} \mathrm{C}$ and $90-95 \% \mathrm{RH}$ during 2018 and 2019 seasons

\begin{tabular}{|c|c|c|c|c|c|c|}
\hline Treatments & 0 day & 15 days & 30 days & 45 days & 60 days & Mean \\
\hline & \multicolumn{6}{|c|}{ 2017-2018 season } \\
\hline$T_{1}: 100 \%$ inorganic & $10.75 \mathrm{c}$ & $12.27 \mathrm{a}$ & $12.30 \mathrm{a}$ & 12.73 a & $13.20 \mathrm{~b}$ & $12.25 \mathrm{~b}$ \\
\hline $\mathrm{T}_{2}: 66.6 \%$ inorganic $+33.6 \%$ organic & $11.55 \mathrm{~b}$ & $11.58 \mathrm{~d}$ & $11.88 \mathrm{~b}$ & $12.12 \mathrm{~d}$ & $12.28 \mathrm{~b}$ & $11.88 \mathrm{~d}$ \\
\hline $\mathrm{T}_{3}: 50 \%$ inorganic $+\mathbf{5 0} \%$ organic & $12.15 \mathrm{a}$ & $12.17 \mathrm{~b}$ & $12.35 \mathrm{a}$ & $12.67 \mathrm{~b}$ & $12.66 \mathrm{a}$ & $12.40 \mathrm{a}$ \\
\hline $\mathrm{T}_{4}: 33.3 \%$ inorganic $+66.6 \%$ organic & $11.49 \mathrm{~b}$ & $11.53 \mathrm{e}$ & $11.71 \mathrm{~b}$ & $11.90 \mathrm{e}$ & $12.02 \mathrm{c}$ & $11.73 \mathrm{e}$ \\
\hline $\mathrm{T}_{5}: 100 \%$ organic & $11.77 b$ & $11.81 \mathrm{c}$ & $11.80 \mathrm{~b}$ & $12.32 \mathrm{c}$ & $12.30 \mathrm{~b}$ & $12.00 \mathrm{c}$ \\
\hline \multirow[t]{2}{*}{ Mean } & $11.54 \mathrm{e}$ & $11.87 \mathrm{~d}$ & $12.00 \mathrm{c}$ & $12.34 \mathrm{~b}$ & $12.49 \mathrm{a}$ & --- \\
\hline & \multicolumn{6}{|c|}{ 2018-2019 season } \\
\hline $\mathrm{T}_{1}: 100 \%$ inorganic & $10.35 \mathrm{c}$ & $10.65 \mathrm{e}$ & $10.95 \mathrm{e}$ & $10.97 \mathrm{~d}$ & $11.23 \mathrm{c}$ & $10.83 \mathrm{e}$ \\
\hline $\mathrm{T}_{2}: 66.6 \%$ inorganic $+33.6 \%$ organic & $11.18 \mathrm{~b}$ & $11.56 \mathrm{c}$ & $11.71 \mathrm{c}$ & $11.75 \mathrm{c}$ & $11.95 a b$ & $11.63 \mathrm{c}$ \\
\hline $\mathrm{T}_{3}: \mathbf{5 0} \%$ inorganic $+\mathbf{5 0} \%$ organic & $11.61 \mathrm{a}$ & $12.01 \mathrm{a}$ & $12.18 \mathrm{a}$ & $12.22 \mathrm{a}$ & $12.25 \mathrm{a}$ & $12.05 \mathrm{a}$ \\
\hline $\mathrm{T}_{4}: 33.3 \%$ inorganic $+66.6 \%$ organic & $11.14 \mathrm{~b}$ & $11.23 \mathrm{~d}$ & $11.44 \mathrm{~d}$ & $11.69 \mathrm{c}$ & $11.72 \mathrm{~b}$ & $11.44 \mathrm{~d}$ \\
\hline $\mathrm{T}_{5}: 100 \%$ organic & $11.50 \mathrm{a}$ & $11.84 \mathrm{~b}$ & $12.11 \mathrm{~b}$ & $12.13 \mathrm{~b}$ & 12.14 a & $11.94 \mathrm{~b}$ \\
\hline Mean & $11.15 \mathrm{~d}$ & $11.45 \mathrm{c}$ & $11.67 \mathrm{~b}$ & $11.75 a b$ & $11.85 \mathrm{a}$ & --- \\
\hline
\end{tabular}

Means followed by the same letter within a column are not significantly different using DMRT at $P \leq 0.05$ 


\section{Titratable acidity}

Titratable acidity of Washington navel orange fruits at cold storage during 60 days affected by organic and inorganic nitrogen fertilizers (Table 6). The results indicated that titratable acidity was gradually decreased with the incidence of cold storage period in both seasons. Soil application of $66.6 \%$ mineral nitrogen + $33.3 \%$ organic nitrogen $\left(T_{2}\right)$ recorded the highest titratable acidity content in both seasons. These results agree with EI Sayed and EI Sherif (2017) on Washington navel orange and Taha et al., (2018) on apple. As the ripening of the fruits develops, a reduction in titratable acidity is observed. The decrease in acid content was caused by the use of acids in the fruit as a source of energy and the conversion of organic acids to form sugar (Ghosh and Sen 1984).

\section{SSC/acid ratio:}

Data in Table 7 show the effect of organic and inorganic nitrogen fertilizers on SSC/acid ratio of Washington navel orange fruits at cold storage $\left(3 \pm 1^{\circ} \mathrm{C}\right.$ and $90-95 \% \mathrm{RH})$. The results revealed that as the storage period progressed, the SSC/acid ratio was increased. SSC/acid ratio values of $T_{3}$ and $T_{1}$ were the highest in the first season, but $T_{5}$ and $T_{3}$ gave the highest values in the second seasons. In contrast, fruits from $\mathrm{T}_{2}$ had the lowest values of SSC/acid ratio in both seasons. Similar results were obtained by El Sayed and EI Sherif (2017) on Washington navel orange. So, it can be concluded from data in Table 9 that application of $\mathrm{T}_{3} \mathbf{( 5 0 \%}$ inorganic nitrogen $+50 \%$ organic nitrogen) maintain high level of SSC/acid ratio during cold storage at $3 \pm 1^{\circ} \mathrm{C}$ for 60 days.

Table 6: Effect of organic and inorganic nitrogen fertilizers on acidity $\%$ of Washington navel orange fruits during cold storage at $3 \pm 1^{\circ} \mathrm{C}$ and $90-95 \% \mathrm{RH}$

\begin{tabular}{|c|c|c|c|c|c|c|}
\hline Treatments & 0 day & 15 days & 30 days & 45 days & 60 days & Mean \\
\hline & \multicolumn{6}{|c|}{ 2017-2018 season } \\
\hline T1: $100 \%$ inorganic & $1.18 \mathrm{a}$ & $1.17 \mathrm{a}$ & $1.09 \mathrm{e}$ & $0.98 \mathrm{e}$ & $0.98 \mathrm{c}$ & $1.08 \mathrm{~b}$ \\
\hline T2 : $66.6 \%$ inorganic $+33.6 \%$ organic & $1.14 \mathrm{~b}$ & $1.13 \mathrm{~b}$ & $1.13 \mathrm{a}$ & $1.04 \mathrm{~b}$ & $1.04 \mathrm{a}$ & $1.09 \mathrm{a}$ \\
\hline T3 : $\mathbf{5 0} \%$ inorganic $+\mathbf{5 0} \%$ organic & $1.12 \mathrm{bc}$ & $1.12 \mathrm{bc}$ & $1.12 \mathrm{~b}$ & $1.02 \mathrm{c}$ & $1.02 \mathrm{ab}$ & $1.08 \mathrm{~b}$ \\
\hline $\mathrm{T} 4: 33.3 \%$ inorganic $+66.6 \%$ organic & $1.11 \mathrm{c}$ & $1.10 \mathrm{c}$ & $1.11 \mathrm{c}$ & $1.01 \mathrm{~d}$ & $1.01 \mathrm{~b}$ & $1.06 \mathrm{c}$ \\
\hline T5 : $100 \%$ organic & $1.10 \mathrm{c}$ & $1.10 \mathrm{c}$ & $1.10 \mathrm{~d}$ & $1.08 \mathrm{a}$ & $1.00 \mathrm{bc}$ & $1.07 \mathrm{~b}$ \\
\hline \multirow[t]{2}{*}{ Mean } & $1.13 \mathrm{a}$ & $1.12 \mathrm{a}$ & $1.11 \mathrm{~b}$ & $1.02 \mathrm{c}$ & $1.01 \mathrm{~d}$ & --- \\
\hline & \multicolumn{6}{|c|}{ 2018-2019 season } \\
\hline T1: $100 \%$ inorganic & $1.16 \mathrm{a}$ & $1.16 \mathrm{a}$ & $1.06 \mathrm{~b}$ & $1.06 \mathrm{a}$ & $0.96 \mathrm{~b}$ & $1.08 \mathrm{~b}$ \\
\hline T2 : $66.6 \%$ inorganic $+33.6 \%$ organic & $1.14 \mathrm{~b}$ & $1.14 \mathrm{ab}$ & $1.14 \mathrm{a}$ & $1.04 \mathrm{a}$ & $1.04 \mathrm{a}$ & $1.10 \mathrm{a}$ \\
\hline T3 : $50 \%$ inorganic $+\mathbf{5 0} \%$ organic & $1.13 \mathrm{~b}$ & $1.13 \mathrm{bc}$ & $1.03 \mathrm{bc}$ & $0.93 \mathrm{c}$ & $0.93 \mathrm{c}$ & $1.03 \mathrm{c}$ \\
\hline $\mathrm{T} 4: 33.3 \%$ inorganic $+66.6 \%$ organic & $1.11 \mathrm{c}$ & $1.11 \mathrm{c}$ & $1.01 \mathrm{c}$ & $1.01 \mathrm{~b}$ & $0.91 \mathrm{c}$ & $1.03 \mathrm{c}$ \\
\hline T5 : $100 \%$ organic & $1.11 \mathrm{c}$ & $1.11 \mathrm{c}$ & $1.01 \mathrm{c}$ & $0.91 \mathrm{c}$ & $0.91 \mathrm{c}$ & $1.01 \mathrm{~d}$ \\
\hline Mean & $1.13 \mathrm{a}$ & $1.13 \mathrm{a}$ & $1.05 \mathrm{~b}$ & $0.99 \mathrm{c}$ & $0.95 \mathrm{~d}$ & --. \\
\hline
\end{tabular}


Table 7: Effect of organic and inorganic nitrogen fertilizers on SSC/acid ratio of Washington navel orange fruits during cold storage at $3 \pm 1^{\circ} \mathrm{C}$ and $90-95 \% \mathrm{RH}$

\begin{tabular}{|c|c|c|c|c|c|c|}
\hline Treatments & 0 day & $\begin{array}{l}15 \\
\text { days }\end{array}$ & $\begin{array}{l}30 \\
\text { days }\end{array}$ & $\begin{array}{l}45 \\
\text { days }\end{array}$ & $\begin{array}{l}60 \\
\text { days }\end{array}$ & Mean \\
\hline & \multicolumn{6}{|c|}{ 2017-2018 season } \\
\hline $\mathrm{T}_{1}: \mathbf{1 0 0 \%}$ inorganic & $9.11 \mathrm{e}$ & $10.49 a b$ & $11.28 \mathrm{a}$ & $12.99 \mathrm{a}$ & $13.47 \mathrm{a}$ & $11.46 \mathrm{a}$ \\
\hline $\mathrm{T}_{2}: \mathbf{6 6 . 6 \%}$ inorganic $+33.6 \%$ organic & $10.13 \mathrm{~d}$ & $10.07 \mathrm{c}$ & $10.51 \mathrm{c}$ & $11.65 \mathrm{c}$ & $11.80 \mathrm{~d}$ & $10.83 \mathrm{~d}$ \\
\hline $\mathrm{T}_{3}: \mathbf{5 0} \%$ inorganic $+\mathbf{5 0} \%$ organic & $10.84 \mathrm{a}$ & $10.79 \mathrm{a}$ & $10.98 \mathrm{ab}$ & $12.42 \mathrm{~b}$ & $12.41 \mathrm{~b}$ & $11.48 \mathrm{a}$ \\
\hline $\mathrm{T}_{4}: 33.3 \%$ inorganic $+66.6 \%$ organic & $10.32 \mathrm{c}$ & $10.30 \mathrm{bc}$ & $10.55 \mathrm{c}$ & $11.78 \mathrm{c}$ & $11.90 \mathrm{~cd}$ & $10.97 \mathrm{c}$ \\
\hline $\mathrm{T}_{5}: 100 \%$ organic & $10.67 \mathrm{~b}$ & $10.74 \mathrm{a}$ & $10.72 \mathrm{bc}$ & $11.37 \mathrm{~d}$ & $12.31 \mathrm{bc}$ & $11.16 \mathrm{~b}$ \\
\hline \multirow[t]{2}{*}{ Mean } & $10.21 \mathrm{e}$ & $10.47 \mathrm{~d}$ & $10.80 \mathrm{c}$ & $12.04 \mathrm{~b}$ & $12.37 \mathrm{a}$ & --- \\
\hline & \multicolumn{6}{|c|}{ 2018-2019 season } \\
\hline$T_{1}: 100 \%$ inorganic & $8.93 \mathrm{~d}$ & $9.17 \mathrm{c}$ & $10.33 \mathrm{c}$ & $10.35 \mathrm{c}$ & $11.69 \mathrm{~b}$ & $10.09 \mathrm{~d}$ \\
\hline $\mathrm{T}_{2}: 66.6 \%$ inorganic $+33.6 \%$ organic & $9.80 \mathrm{c}$ & $10.14 \mathrm{~b}$ & $10.27 \mathrm{c}$ & $11.29 \mathrm{~b}$ & $11.49 \mathrm{~b}$ & $10.59 \mathrm{c}$ \\
\hline $\mathrm{T}_{3}: \mathbf{5 0} \%$ inorganic $+\mathbf{5 0} \%$ organic & $10.27 \mathrm{a}$ & $10.62 \mathrm{a}$ & $11.82 \mathrm{a}$ & $13.14 \mathrm{a}$ & 13.16 a & $11.80 \mathrm{a}$ \\
\hline $\mathrm{T}_{4}: 33.3 \%$ inorganic $+66.6 \%$ organic & $10.01 \mathrm{~b}$ & $10.11 \mathrm{~b}$ & $11.33 \mathrm{~b}$ & $11.57 \mathrm{~b}$ & $12.88 \mathrm{a}$ & $11.18 \mathrm{~b}$ \\
\hline $\mathrm{T}_{5}: 100 \%$ organic & $10.36 \mathrm{a}$ & $10.66 \mathrm{a}$ & 11.99 a & $13.32 \mathrm{a}$ & $13.34 \mathrm{a}$ & $11.93 \mathrm{a}$ \\
\hline Mean & $9.87 \mathrm{e}$ & $10.14 \mathrm{~d}$ & $11.14 \mathrm{c}$ & $11.93 \mathrm{~b}$ & $12.51 \mathrm{a}$ & -- \\
\hline
\end{tabular}

Means followed by the same letter within a column are not significantly different using DMRT at $P \leq 0.05$

\section{Vitamin C:}

Data presented in Table 8 show that, vitamin C (ascorbic acid) content in Washington navel orange fruits under cold storage $\left(3 \pm 1^{\circ} \mathrm{C}\right.$ and $\left.90-95 \% \mathrm{RH}\right)$ was decreased gradually as storage period prolonged. Moreover, fruits harvested from trees that treated by $T_{2}$ and $T_{1}$ in the first season and $T_{3}$ and $T_{2}$ in the second one had significantly the highest values of ascorbic acid as compared to the other treatments during storage period. On the other hand, $\mathrm{T}_{4}$ had the lowest value of ascorbic acid as compared to other treatments in both seasons. So, it can be concluded that application of $T_{2}$ and $T_{3}$ are most effective in preventing ascorbic acid losses from fruits during cold storage. The same trend was also observed in the previous study by Candir et al., (2013) and El Sayed and El Sherif (2017) on Washington navel orange fruits. In this respect, Omar and Belal (2013) reported that, Washington navel orange fruit sprayed with compost tea and filtered biogas slurry liquid had the maximum content of ascorbic acid at the end of storage period. 
H. A. Ennab, et al.,

Table 8: Effect of organic and inorganic nitrogen fertilizers on vitamin $\mathrm{C} \mathrm{mg/100} \mathrm{ml}$ juice of Washington navel orange fruits during cold storage at $3 \pm 1^{\circ} \mathrm{C}$ and $90-95 \% \mathrm{RH}$

\begin{tabular}{|c|c|c|c|c|c|c|}
\hline Treatments & 0 day & 15 days & 30 days & 45 days & 60 days & Mean \\
\hline \multicolumn{7}{|c|}{ 2017-2018 season } \\
\hline $\mathrm{T}_{1}: 100 \%$ inorganic & $54.93 \mathrm{a}$ & $54.24 \mathrm{ab}$ & $52.82 \mathrm{~b}$ & $51.36 \mathrm{~b}$ & $50.00 \mathrm{~b}$ & $52.67 \mathrm{~b}$ \\
\hline $\mathrm{T}_{2}: 66.6 \%$ inorganic $+33.6 \%$ organic & $55.78 \mathrm{a}$ & $55.65 \mathrm{a}$ & $55.11 \mathrm{a}$ & $54.22 \mathrm{a}$ & $53.69 \mathrm{a}$ & 54.89 a \\
\hline $\mathrm{T}_{3}: \mathbf{5 0} \%$ inorganic $+\mathbf{5 0} \%$ organic & $53.86 \mathrm{ab}$ & $53.59 \mathrm{~b}$ & $51.42 \mathrm{c}$ & $49.11 \mathrm{c}$ & $47.48 \mathrm{c}$ & $51.09 \mathrm{c}$ \\
\hline $\mathrm{T}_{4}: 33.3 \%$ inorganic $+66.6 \%$ organic & $50.23 \mathrm{~b}$ & $49.45 \mathrm{c}$ & $47.61 \mathrm{~d}$ & $46.00 \mathrm{~d}$ & $44.10 \mathrm{~d}$ & $47.47 \mathrm{~d}$ \\
\hline $\mathrm{T}_{5}: 100 \%$ organic & $53.14 \mathrm{ab}$ & $52.97 \mathrm{~b}$ & $51.63 \mathrm{bc}$ & $49.43 \mathrm{c}$ & $47.68 \mathrm{c}$ & $50.97 \mathrm{c}$ \\
\hline \multirow[t]{2}{*}{ Mean } & 53.58 a & $53.18 \mathrm{a}$ & $51.71 \mathrm{~b}$ & $50.02 \mathrm{c}$ & $48.59 \mathrm{~d}$ & -- \\
\hline & \multicolumn{2}{|c|}{ 2018-2019 season } & \multirow[b]{2}{*}{$49.32 \mathrm{~b}$} & \multirow[b]{2}{*}{$47.24 \mathrm{c}$} & & \\
\hline$T_{1}: 100 \%$ inorganic & $52.33 \mathrm{bc}$ & $52.00 \mathrm{c}$ & & & $45.00 \mathrm{~b}$ & $49.17 \mathrm{c}$ \\
\hline $\mathrm{T}_{2}: 66.6 \%$ inorganic $+33.6 \%$ organic & $54.96 \mathrm{ab}$ & $54.53 \mathrm{~b}$ & 52.77 a & $50.42 \mathrm{~b}$ & $48.63 \mathrm{a}$ & $52.26 \mathrm{~b}$ \\
\hline $\mathrm{T}_{3}: \mathbf{5 0} \%$ inorganic $+\mathbf{5 0} \%$ organic & $56.61 \mathrm{a}$ & $56.20 \mathrm{a}$ & $54.00 \mathrm{a}$ & $51.90 \mathrm{a}$ & 49.94 a & $53.73 \mathrm{a}$ \\
\hline $\mathrm{T}_{4}: 33.3 \%$ inorganic $+66.6 \%$ organic & $49.57 \mathrm{c}$ & $49.22 \mathrm{~d}$ & $46.83 \mathrm{c}$ & $44.95 \mathrm{~d}$ & $42.73 \mathrm{c}$ & $46.66 \mathrm{~d}$ \\
\hline $\mathrm{T}_{5}: 100 \%$ organic & $50.45 \mathrm{c}$ & $49.86 \mathrm{~d}$ & $46.94 \mathrm{c}$ & $45.00 \mathrm{~d}$ & $43.18 \mathrm{c}$ & $47.08 \mathrm{~d}$ \\
\hline Mean & 52.78 a & $52.36 \mathrm{a}$ & $49.97 \mathrm{~b}$ & $47.90 \mathrm{c}$ & $45.89 \mathrm{~d}$ & --- \\
\hline
\end{tabular}

Means followed by the same letter within a column are not significantly different using DMRT at $P \leq 0.05$

\section{Conclusion}

In light of this study it can be concluded that, combined application of poultry manure as organic nitrogen and ammonium sulphate as inorganic nitrogen causes an increase in fruit quality at picking date. Under cold storage conditions, organic and inorganic nitrogen applications, especially $T_{3}(305.8 \mathrm{~kg} / \mathrm{feddan}$ ammonium sulphate +2.73 ton/feddan poultry manure) was the best treatment for maintaining the fruit quality of Washington navel orange over other treatments, where it exhibited the least weight loss and decay percentages as well as maintaining fruit firmness, titratable acidity, soluble solids content, SSC/acid ratio and ascorbic acid in the highest levels. On the basis of these results, it can be concluded that the treatments of $305.8 \mathrm{~kg} / \mathrm{feddan}$ ammonium sulphate +2.73 ton/feddan poultry manure was the most effective method in maintaining the quality of Washington navel orange fruits at picking date as well as under cold storage at $3 \pm 1$ with $\mathbf{9 0 - 9 5}$ RH tell 60 days.

\section{REFERENCES}

A.O.A.C. (1990). Association of official analytical chemists. Official Methods of Analysis. 15th Ed. Washington D.C., USA.

Abd El Migeed, M.M., M.M. Saleh and E.A. Mostafa (2007). The beneficial effect of minimizing mineral nitrogen fertilization on Washington navel orange trees by using organic and biofertilizers. World J. Agric. Sci., 3(1): 80 - 85 .

Ahmed, F.F., A.H. Abdelaal and M.H. Faraag (2013). Partial replacement of inorganic $N$ fertilizer in Balady mandarin orchards by using organic and biofertilization. Stem 4(2):21 - 28.

Benge, J.R., N.H. Banks, R. Tillman and H.N. Silva (2000). Pairwise comparison of the storage potential of kiwifruit from organic and conventional 
production systems, New Zealand Journal of Crop and Horticultural Science, 28(2): 147 - 152.

Candir, E., M. Kamiloglu, D. Ustun and G.T. Kendir (2013). Comparison postharvest quality of conventionally and organically grown Washington navel orange. Journal of Applied Botany and Food Quality 86:59 - 65.

Caruso, G., S. Conti and G. La Rocca (2011). Influence of crop cycle and nitrogen fertilizer form on yield and nitrate content in different species of vegetables. Adv. Hortic. Sci., 25(2):81 $-89$.

Ceglie, F.G., M.L. Amodio and G. Colelli (2016). Effect of organic production systems on quality and postharvest performance of horticultural produce. Horticulturae, 2, 4; doi:10.3390/horticulturae2020004.

Duncan, D.B. (1955). Multiple range and multiple F. test. Biometries.11: 1 - 42.

EI Sayed, S.A. and A.R. El Shereif (2017). Use of natural raw material mixture and natural raw potassium as substitute for chemical fertilizers in feeding Washington navel orange trees under Kafr El Sheikh conditions. J. Plant Production, Mansoura Univ., 8(5):569 - 576.

Ennab, H.A., M.A. M. Soliman and G. B. Mikhael (2018). Replacing nitrogen fertilization by using organic and biofertilizers on Costata persimmon trees. J. Product. \& Dev., 23(1): 39 59.

Ghosh, S.K. and S.K. Sen (1984). Extension of storage life of sweet orange (Citrus sinensis Osbeck) cv. Mosambi. South Indian Hort., 32: 16 22.

Ibrahim, A.M and M.F. Maklad (2014). Effect of partial replacement of mineral nitrogen fertilization by organic from on yield and leaf mineral content of navel orange trees. J. Biol. Chem. Environ. Sci., 9(4): 176 - 186.
Kassem, H.A. and M.B. El Sabrout (2002). Effect of fertilization with nitrogen and potassium on fruit quality and storability of Washington navel orange trees grown in sandy soils. J. Adv. Agric. Res., 7(3):552 - 569.

Malhi, S.S., L.J. Piening and D.J. Macpherson (1989). Effect of copper on stem melanosis and yield of wheat: sources, rates and methods of application. Plant Soil 119:199 - 204.

Mansour, A.E.M. and E.A. Shaaban (2007). Effect of different sources of mineral $\mathbf{N}$ applied with organic and bio fertilizers on fruiting of Washington navel orange trees. Journal of Applied Sciences Research, 3(8):764 - 769.

Marschner, H. (1995). Mineral nutrition of higher plants. Second edition. Academic Press. London, UK.

Masclaux-Daubresse, C., F. DanielVedele, J. Dechorgnat, F. Chardon, L. Gaufichon and A. Suzuki (2010). Nitrogen uptake, assimilation and remobilization in plants: challenges for sustainable and productive agriculture. Annals of Botany 105:1141 - 1157.

Mehmood, T., S. Hussain, U. Farooq and K. Akram (2016). Impact of different farming systems (conventional, integrated and organic) and storage time on physiological characteristics of Kinnow mandarin (Citrus nobilis $x$ Citrus deliciosa). Pak. J. Agri. Sci., 53(1): 7 - 15 .

Omar, A.E.K. and E.A. Belal (2013). Storability and quality improvement of Washington navel orange fruit (Citrus sinensis Osbeck) by safe preharvest treatments. Biological Agriculture \& Horticulture: An International Journal for Sustainable Production Systems, DOI: 10. 1080/ 01448765. 2013. 845113.

Page, A.L., R.H. Miller and D.R. Keeney (1982). Methods of soil analysis part 2: chemical and microbiological 
properties second edition. Agronomy 920 Am. Soc. Agron. Inc. Soil Sci. Soc. Am. Inc. Pub. Madison, Wisconsin, USA.

Rangana, S.H. (1977). Manual of analysis of fruit and vegetable products. Tata McGraw-Hill publishing Company Limited, New Delhi, pp: 634.

Sharma, A., V.K. Wali, P. Bakshi, V. Sharma, V. Sharma, M. Bakshi and S. Rani (2016). Impact of poultry manure on fruit quality attributes and nutrient status of guava (Psidium guajava.) cv. L 49 plant. Indian Journal of Agricultural Sciences 86 (4):533 - 40.
Snedecor, G.W. and W.G. Cochran (1990). Statistical methods. 7th Ed. Iowa State Univ. Press. Ames., lowa, USA, p. 593.

Taha, N.M., N.H. Shakweer and R.M. ElShahat (2018). Impact of different sources of natural, mineral and biofertilizers on apple trees performance, growth and yield on sandy soil. Egypt. J. Soil Sci., 58(1):113 - 126.

Zaghloul, A.E., A.A. El Abd and S.A. Fawaz (2010). Effect of some nutrient fertilizers on fruit quality and storability of Washington navel orange (Citrus sinensis Osbeck). Egyptian J. Hort., 38(1): 69 - 82. 
تأثير الأسمدة النيتروجينية العضوية والمعدنية على أشجار البرتقال أبو سرة II. جودة الثمار أثناء التخزين البارد
حسن أبو الفتوح عناب(')، مرفت عبد المجيد الثيمى(؟)، مها حسيب عبدالعزيز(r)(

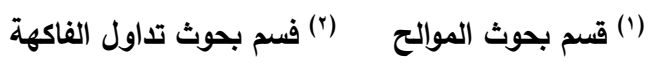

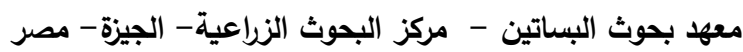

الملخص العربى

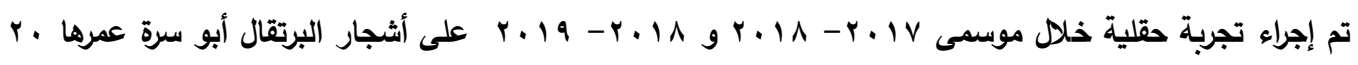
سنة مطعومة على أصل النارنج ومسافة الزراعة ه × ه متر فى مزرعة خاصة بمحافظة كفر الشيخ، مصر ، لتقييم تاثير

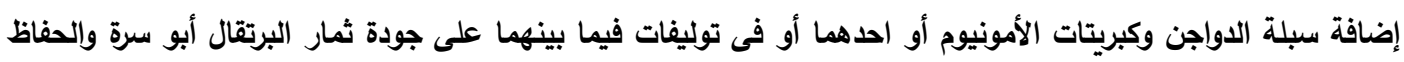

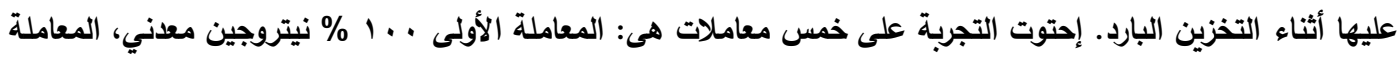

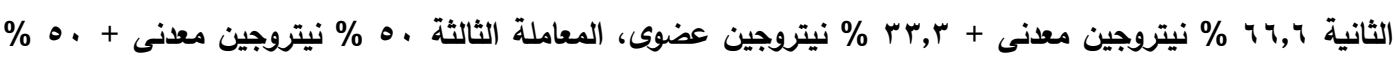

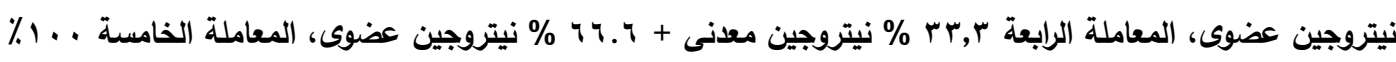
نتروجين عضوى.

وقت جمع الثمار ، تم اخذ عينات من الثمار و نقلها مباشرة إلى معمل محطة بحوث البساتين بسخا ، محافظة كفر

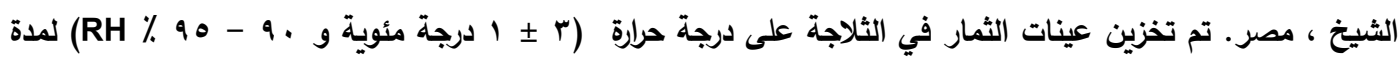

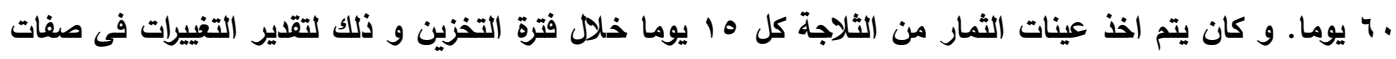

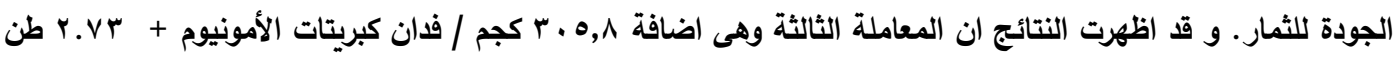

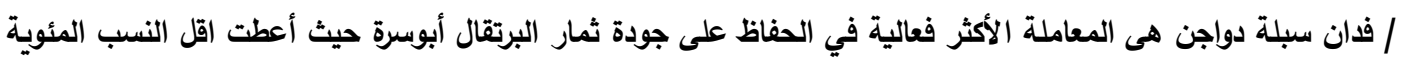

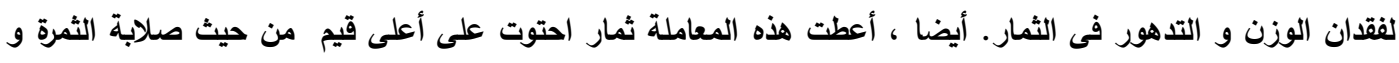

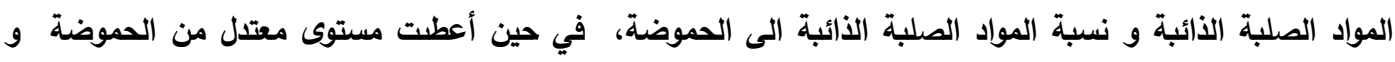
فيتامين C مقارنة مع المعاملات الأخرى.

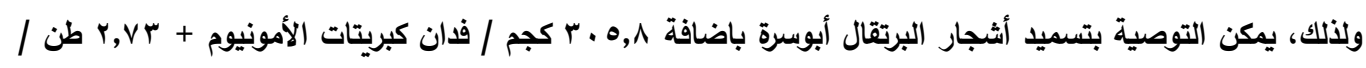

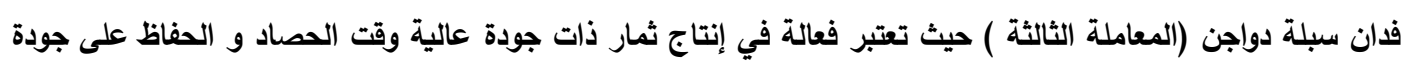
الثمارأثناء فترة التخزين.

أسماء السادة المحكمين

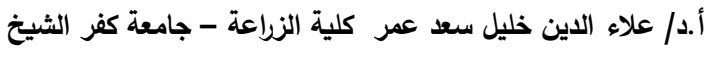

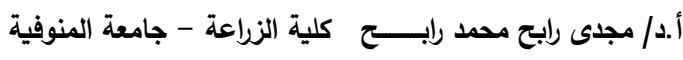


H. A. Ennab, et al., 